\title{
Partai Politik: Tinjauan Strategi Dalam Meraih Dukungan Massa
}

\author{
${ }^{1}$ Syahrul Ibad, ${ }^{2}$ Musdalifah \\ ${ }^{12}$ Fakultas Sosial dan Humaniora, Universitas Ibrahimy \\ Situbondo,Indonesia \\ Email: ${ }^{1}$ sinbad.sit@gmail.com, ${ }^{2}$ lifamudalifa.sit@gmail.com
}

Received: 06 Desember 2019; Revised: 05 Februari 2020; Accepted: 12 Februari 2020

\begin{abstract}
This study discusses political parties reviewing strategies in gaining mass support, the strategy carried out by political parties is to achieve predetermined goals which in this case are referred to as the vision and mission of political parties using techniques, tricks, methods and implementation of tasks by utilizing party structure, so that the work program is in accordance with the wishes of the community. Meanwhile, to uncover the strategy of political parties in gaining mass support, a library research method or approach is used. Literature study or literature can be interpreted as a series of activities related to library data collection methods, reading and recording and processing research materials. Research results show that strategy of political parties in gaining the support of the masses is always trying to fix the party from the party's internal and external parties, so that the party can provide a better change for the community through political party programs and through power struggles in general elections.
\end{abstract}

Keywords: Political Parties; Strategy; Mass Support

\begin{abstract}
Abstrak
Penelitian ini membahas tentang partai politik tinjauan strategi dalam meraih dukungan massa, strategi yang dilakukan partai politik ialah untuk mencapai tujuan yang sudah ditentukan sebelumnya yang dalam hal ini disebut sebagai dengan visi dan misi partai politik dengan menggunakan teknik, trik, cara maupun pelaksanaan tugas dengan memamfaatkan struktur partai, sehingga program kerja sesuai dengan keinginan masyarakat. Sedangkan untuk mengungkap strategi partai politik dalam meraih dukungan massa digunakan metode atau pendekatan kepustakaan, Studi pustaka atau kepustakaan dapat diartikan sebagai serangkaian kegiatan yang berkenaan dengan metode pengumpulan data pustaka, membaca dan mencatat serta mengolah bahan penelitian. Hasil Penelitian menunjukkan bahwa strategi partai politik dalam meraih dukungan massa adalah selalu berusaha membenahi partai dari internal partai maupun ekternal partai, sehingga partai bisa memberikan perubahan yang lebih baik bagi masyarakat melalui program partai politik maupun melalui perebutan kekuasaan dalam pemilihan umum.
\end{abstract}

Kata kunci: Partai Politik; Strategi; Dukungan Massa

Link DOI : http://dx.doi.org/10.31314/pjia.8.2.89-100.2019 


\section{PENDAHULUAN}

Proses demokrasi di Indonesia telah berubah secara fundamental dan menemukan jati dirinya. Demokrasi di Indonesia sudah sampai pada titik yang tidak mungkin kembali kebelakang lagi. Hambatan-hambatan terjadi pada nilai-nilai yang ada di masyarakat dan kondisi politik sebuah bangsa. Indonesia bisa dikatakan negara yang sukses menuju demokrasi, meskipun dalam penerapannya masih tertatih-tatih. Pasang surut yang dilalui rakyat Indonesia untuk membangun demokrasi membuahkan hasil dan mendapat pengakuan internasional.

Berangkat dari pengakuan internasional terhadap demokrasi yang masih perlu pembenahan untuk menuju demokrasi yang sebenarnya, demokrasi yang di bagun Indonesia perlu adanya interaksi antara masyarakat dan pemerintah. Dari itu, partai politik menjadi mediator antara masyarakan dan pemerintah. Akan tetapi, sekarang partai politik tidak lagi mempedulikan kepentingan rakyat padahal kalau kita lihat partai politik adalah wadah asprirasi masyarakat untuk menuju demokrasi yang sebenarnya. Sebuah kenyataan yang tak dapat dipungkiri bahwa keberadaan partai politik sangat berpengaruh dalam proses politik di Indonesia hal ini bisa kita lihat dengan banyaknya bermunculan partaipartai baru sebutlah PBB, PKS, PAN, PKB, PPNUI, PSI dan lain sebagainya. Keberadaan partai-partai baru tersebut lahir dari sempalan-sempalan partai-partai yang ada sebelumnya (PPP, PDI dan Golkar).

Di Indonesia, beberapa partai sering mengubah atribut, ideologi, asas, dan sentimen Islam. Sebutlah, PBB, PKS, PAN, PPP, PKB, PSI, PPNUI, dan lainlain. Partai-partai ini langsung maupun tidak langsung selalu menggunakan atribut
Islam dalam desain partai, pola kampanye, pola rekruitmen, maupun ketika melakukan transaksi politik pada pemilihnya (Hidayat, Komaruddin dan Haryono, 2004).

Partai merupakan suatu sistem terbuka, dikelilingi oleh lingkungan. Dalam lingkungan itu terdapat sejumlah tantangan serta tekanan, oleh karena itu partai politik selalu siap terhadap kemungkinan-kemungkinan yang akan terjadi. Dalam hal ini partai politik mempunyai bermacam-macam strategi untuk menanggulanginya seperti dalam hal meraih dukungan massa untuk memperoleh dukungan, kebanyakan partai politik menggandeng atau memasukkan ulama/kyai kedalam struktur partai politik sehingga masyarakat simpatik kepada partai politik tersebut dan mendukungnya.

Sadar atau tidak sadar masyarakat sering mengikuti perkataan yang di ucapkan oleh tokoh masyarakat lebih-lebih lagi oleh ulama. Menurut (Azra, 2002) mengatakan kalau kita lihat pada satu pihak, ulama bergerak dalam bidangbidang keagamaan, khususnya dalam di bidang syariah atau fikih. Dalam kontek ini, ulama berfungsi tidak hanya sebagai "penjaga" hukum Tuhan (custodian of God's law) dari berbagai kemungkinan penyimpangan. Kedudukan ini diperkuat pula dengan pemberian status tinggi kepada mereka sebagai "pewaris para nabi” (waratsa al-anbiya').

Dengan demikian lengkaplah aura mereka keilahian dan kesucian yang mereka sandang. Sebab itu pula, ulama setidaknya dari sudut pandang masyarakat awam- memiliki aura sakralitas, yang pada gilirannya terjewantahkan dalam kekuatan kharisma tertentu. Bukan secara kebetulan partai politik yang ada di Indonesia kebanyakan selalu menggunakan atribut agama, dan menggandeng ulama atau memasukkan kedalam struktur partai, lalu 
apakah hal ini merupakan manuvermanuver politik yang dilakukan oleh partai politik sebagai strategi partai politik untuk memperoleh dukungan massa.

Partai politik merupakan produk dari demokrasi, adanya partai politik menunjukkan bahwa keberadaan masyarakat kita beragam dan bermacammacam kepentingan hal itu terbukti dengan banyaknya bermunculan partai politik baru untuk menampung kepentingankepentingan masyarakat yang berbedabeda itu. Tetapi kenyataannya pada saat ini masyarakat tidak percaya dengan partai politik, hal ini terbukti dengan adanya calon independen dalam PILKADA, sehingga partai politik berlomba-lomba meraih dukungan massa untuk mendapatkan dukungan dari masyarakat.

Dalam suatu organisasi partai politik seyogyanya dihayati interaksi fungsional yang menunjukkan adanya suatu proses aliran yang berputar dalam rangka menjaga eksistensi sistem itu. Yang dalam sistem itu sendiri banyak memiliki beberapa aturan-aturan yang telah ditetapkan bersama.

Hal ini senada apa yang dikatakan (Soebekti, E. Achmad, 2002) dalam partai sudah barang tentu ada konflik-konflik yang terjadi baik itu konflik intern maupun ekstern, hal ini bisa dikatakan ciri suatu partai tertentu. Dapat dikatakan bahwa budaya politik konflik intern partai merupakan ciri khas partai-partai politik di Indonesia, partai-partai Islam tidak terlepas dari tragedi tersebut. Partai politik tidak dapat pula melepaskan warisan semacam itu, sehingga strategi partai untuk mencapai tujuan-tujuan yang telah ditetapkan terhambat dipersimpangan jalan.

Meskipun ada beberapa kendala dan hambatan yang dialami suatu partai politik tetapi yang terpenting adalah proses yang dilakukan partai untuk menjadi Copyright (c) 2019, Publik (Jurnal Ilmu Administrasi), ISSN: 2301-573X (Print), ISSN: 2581-2084 (Online) penyambung aspirasi masyarakat, yaitu dari masyarakat ke pemerintahan dan sebaliknya, harus dilihat sebagai suatu kenyataan, seperti juga pengaruh dari luar masyarakat terhadap sistem politik. Oleh karena itu strategi partai politik dalam meraih dukungan massa merupakan suatu proses partai politik, sehingga untuk sementara atau seterusnya suatu keadaan yang mantap atau keadaan ekuilibrium yang dinamis (dalam arti masih tetap responsif terhadap keadaan) akan tetap diperoleh oleh partai politik.

Banyak penelitian menggambarkan strategi partai dalam pemenangan dan untuk mencapai kekuasaan (Lindawati, 2014) dalam hasil penelitiannya hanya berfokus pada satu strategi partai dan melalui Kampanye, Sosialisasi dan pendidikan politik kepada simpatisan dan masyarakat umum secara terus menerus dengan tujuan membentuk citra politik yang positif baik bagi partai maupun bagi calon-calon legislatif itu sendiri begitu juga dengan penelitian (Ibad, 2008) Hanya memfokuskan partai tertendu didaerah sehingga hasil yang dipatkan dalam lingkup daerah dan penelitian (Sugiarto, Pratiwi, Akbar, Politik, \& Soedirman, 2014) dalam pemenangan Kepala Daerah yang menyimpulkan pada strategi yang dilakukan oleh calon sendiri harus berkenaan pada ekonomi masyarakat.

Dalam strategi partai meraih dukungan massa secara umum pasti ada kemiripan dan kesamaan, hal ini dikarenakan karena partai politik merupakan organisasi yang mempunyai visi dan misi yang akan mereka capai, akan tetapi terkadang partai politik melupakan hal itu dan yang terpenting mencapai kekuasaan dan dukungan.

Maka seharusnyalah strategi partai politik harus konsisten dengan nilai dasar dan visi misi partai, sehingga perlu digambarkan dan dianalisis tentang strategi 
partai secara umum untuk meraih dukungan massa.

\section{METODE PENELITIAN}

Metode yang digunakan dalam kajian ini menggunakan metode atau pendekatan kepustakaan (library research), Studi pustaka atau kepustakaan dapat diartikan sebagai serangkaian kegiatan yang berkenaan dengan metode pengumpulan data pustaka, membaca dan mencatat serta mengolah bahan penelitian (Zed, 2003)

Dalam penelitian studi pustaka setidaknya ada empat ciri utama yang penulis perlu perhatikan diantaranya: Pertama, peneliti mengumpulkan teks (nash) atau data yang berkaitan dengan strategi partai politik tanpa batasan ruang dan waktu. Kedua, data pustaka tersebut kami verifikasi kesesuiannya dengan judul dan dikelompokkan berdasarkan operasional penelitian. Ketiga, data kami analisis berdasarkan pustakan dan data yang ada. Keempat, penarikan kesimpulan dan saran yang dihasilkan dari analisis yang kemudian disandingkan dengan teori strategi maupun partai politik.

\section{HASIL DAN PEMBAHASAN Strategi Partai Politik}

Untuk memahami strategi partai politik alangkah baiknya terlebih dahulu kita pahami strategi secara umum dan strategi politik, untuk memahami strategi secara umum telah disampaikan diatas. Tetapi untuk memahami strategi politik yang dikutip dari buku Teori-teori politik strategi politik sangat penting karena dalam hal itu dapat dianalisis arah dan tujuan politik yang hendak dicapai. Menurut (Hidayat, 2002) strategi dalam pengertian juga bisa diartikan sebagai suatu kerangka rencana untuk merugikan atau bisa pula menguntungkan kelompok lain. Strategi partai politik merupakan hal yang penting dalam melakukan dan menata partai politik untuk menjadi acuan perencanaan yang akan dilakukan oleh sebuah partai, akan tetapi yang terpenting bagi partai politik adalah proses yang dilakukan partai untuk menjadi penyambung aspirasi masyarakat.

Secara umum dalam organisasi partai politik pasti memiliki tujuan yang hendak dan akan dicapai yang disebut visi misi organisasi. Partai politik di Indonesia mempunyai formulasi strategi yang sama secara umum tetapi secara teknis berbeda. Formulasi strategi dapat digambarkan sebagai berikut:

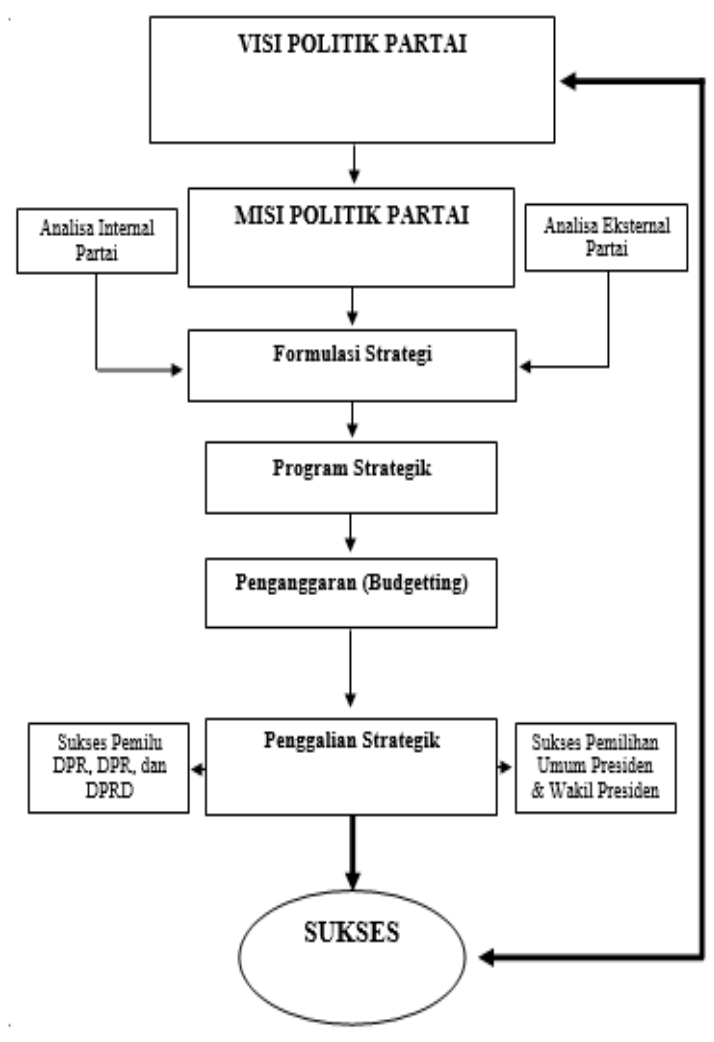

Gambar 1

Formulasi Strategi Secara umum Sukses

Strategi partai politik dalam meraih dukungan massa merupakan suatu proses partai politik, sehingga untuk sementara atau seterusnya suatu keadaan yang mantap atau keadaan ekuilibrium yang dinamis. 
Untuk mencapai strategi tersebut ada beberapa hal yang harus dilakukan yaitu:

\section{Pembenahan Dalam Diri Partai (Internal)}

Strategi partai politik secara internal yaitu pembenahan dalam diri partai dimana memantapkan fungsi organisasi dan konsulidasi dengan kader-kadernya, sehingga menjadi partai yang dapat diandalkan dan memiliki tanggung jawab. Dengan fungsi organisasi dan konsulidasi yang resposif dan mantap akan membentuk pembenahan dalam diri partai (internal).

Untuk itu, dalam melakukan pembenahan dalam diri partai, dalam penelitian ini yang dimaksud strategi internal pembenahan dalam diri partai politik adalah meminimalisir konflik antar pengurus partai, penentuan target yang akan dicapai, dan perkaderan dengan cara pengenalan partai dan pelatihan tentang partai. Hal-hal yang bersangkutan dengan strategi partai dalam internal yakni pembenahan dalam diri partai akan dikaji satu-persatu yaitu:

\section{A. Meminimalisir konflik antar pengurus partai.}

Dalam suatu organisasi terdapat konflik-konflik yang terjadi baik itu konflik internal maupun eksternal. Hal ini terjadi karena berbeda-bedanya kepantingan atau pendapat yang ada, baik di internal maupun eksternal partai. kalau kita cermati partai-partai yang ada saat ini sudah barang tentuk mengalamai konflik dan hal itu merupakan budaya politik. Konflik internal partai merupakan ciri partai-partai politik di Indonesia. Akan tetapi konflik yang ada tidak dapat dibiarkan begitu saja, konflik ini bisa menjadi bom waktu dalam partai yang sewaktu-waktu bisa mengakibatkan perpecahan sehingga strategi partai untuk mencapai tujuan-tujuannya terhambat dengan adanya konflik tersebut.
Konfik dalam kepengurusan (internal partai) memang tidak bisa dibiarkan begitu saja dan konflik tidak bisa dihilangkan dalam organisasi, tetapi setidaknya ada upaya atau usaha untuk meminimalisir konflik tersebut seperti apa yang dilakukan kebanyakan partai untuk meminimalisir konflik adalah "Upaya untuk penataan dan pengembangan organisasi terutama ditekankan pada kosolidasi organisasi yang meliputi antara lain: musyawarah partai pada setiap jenjang organisasi, rekrutmen anggota, pembinaan anggota, pengadaan sarana tertib administrasi, pembinaan lembaga-lembaga, dan peningkatan komunikasi dan informasi" (Dhakidea, 2004).

Tahapan-tahapan yang dilakukan bukan hanya sekedar penataan dan pengembangan organisasi untuk meminimalisir konflik yang terjadi di internal partai. untuk melaksanakan tahapan-tahapan itu menurut (Dhakidea, 2004) diperlukan langkah-langkah restrukturisasi dan revitalisasi yang dimana: Restrukturisasi, bertujuan dan membenahi organisasi pada setiap tingkat dari pusat, wilayah, cabang, sampai ranting dengan memperhatikan kondisi obyektif partai masing-masing tingkatan. dan Revitalisasi, bertujuan untuk membangkitkan dan memberdayakan potensi partai yang dimiliki. Seluruh komponen partai disegenap jajaran harus diberdayakan dan dihidupkan kembali sehingga medukung kegiatan pemilu sesuai dengan kapasitasnya.

Dengan demikian, meminimalisir konflik internal penting dilakukan oleh sebuah oraganisasi maupun partai politik, konflik yang ada dalam internal partai bisa mengakibatkan terhambatnya tujuan partai dan bisa mengakibatkan perpecahan sehingga melahirkan partai-parati baru. Hal ini terbukti dalam tubuh kepengrusan partai politik yang ada di Indonesia Copyright (C 2019, Publik (Jurnal Ilmu Administrasi), ISSN: 2301-573X (Print), ISSN: 2581-2084 (Online) 
mengalami konflik internal sehingga ada dua kepengurusan dalam partai tersebut.

\section{B. Perkaderan dengan cara pengenalan partai dan pelatihan tentang partai.}

Dalam orgnisasi sudah barang tentu ada pengkaderan hal ini dilakukan untuk menjaring dan memberi pemahaman tentang partai politik, proses perkaderan ini harus dilakukan karena hidup matinya organisasi atau partai di masa yang akan mendatang tergantung pada pengkaderan. Karena pengkaderan merupakan pencarian penggati kepengurusan yang akan mendatang, oleh karena itu semua organisasi seharusnya melakukan proses ini untuk eksis dalam masyarakat.

Menurut (Dhakidea, 2004) terkait dengan pengkaderan di dalam salah satu partai menyadari bahwa kader partai adalah tulang punggung dan harapan masa depan partai. karena itu, pendidikan dan pelatihan serta pembinaan kader partai merupakan kunci keberhasilan perjuangan partai. kader-kader dari berbagai tingkatan dan dari beragam latar belakang unsur, fungsi, profesi dengan demikian merupakan andalan partai yang perlu terus menerus memperoleh perhatian, peluang, kesempatan untuk mengembangkan diri dalam dan bersama partai melalui pendidikan dan pelatihan politik yang teratur, terencana dan terprogram secara sistematis.

Perkaderan bisa juga dikatakan mengajak atau mencari potensi-potensi sumber daya manusia untuk turut aktif dalam organisasi atau partai tersebut dan sekaligus pengganti kepengurusan yang akan mendatang. Hal tersebut dilakukan dengan berbagai cara bisa dilakukan dengan cara pengenalan terhadap partai, pendidikan politik, dan pelatihan yang dilakukan organisai atau partai tertentu.

Pengkaderan merupakan bagian dari formulasi strategi partai politik di
Indonesia dan halus dilakukan sesuai dengan tahapan structural partai dengan selalu melihat kapasitas dan kapabilitas dari seorang kader. Pengkaderan pada umumnya dilakukan dengan 2 cara yaitu: Pertama, Pengkaderan dengan cara pengenalan partai; Kaderisasi yang dilakukan pendekatan individual maupun kekeluargaan. Kedua, Pengkaderan dengan cara pelatihan; kaderirasi yang dilakukan semacam ini dilakukan oleh badan atau organ yang dimiliki partai politik.

Partai politik di Indonesia kebanyakan tidak memiliki mekanisme pengkaderan yang disusun secara bertahap dan jelas. Pengkaderan dalam partai politik sering sekali terlupakan dan terabaikan, akan tetapi partai politik merasa butuh dengan adanya pengkaderan ketika pesta demokrasi akan dilakukan dimana partai membutuhkan pendukung dan massa. Hal ini juga terlihat dalam pengusungan legeslatif dan calon kepala daerah yang tanpa pengkadengan calon legislatif dan calon kepala daerah dengan seenaknya memilih partai politik untuk dijadikan kendaraan mencapai kekuasaan.

\section{Penentuan target yang akan dicapai.}

Target yaitu satu atau beberapa segmen masyarakat yang akan menjadi fokus kegiatan kegiatan (Anwar, M. Khoirul dan Salvina, 2006). Memang sebenarnya targeting adalah persoalahan bagaimana memilih, menyeleksi, dan mejangkau masyarakat yang akan ditetapkan sebagai khalayak sasaran kegitan pemasaran politik. Sedangkan menurut (Nursal, 2004) target juga bisa dikatakan penentuan sasaran yang akan dicapai oleh sebab itu Targeting atau penetepan sasaran adalah memiliki salah satu segmen atau beberapa segmen yang akan dibidik untuk mencapai sasaran obyektif. 
Penentuan target atau penentuan sasaran sesuai dengan visi dan misi melalui program yang telah direncanakan, oleh karena itu penentuan target dalam suatu usaha partai harus ditentukan mengingat program yang akan dijalankan. Contohnya saja dalam pemilihan umum partai harus menentukan target atau perolehan suara sebelum pelaksanaan pencoblosan karena hal ini akan mempengaruhi terhapat usahausaha yang akan dilakukan oleh partai baik memobilisasi massa maupun dalam meraih dukungan massa. Setiap program atau kegiatan sudah barang tentu memiliki sasaran atau target, oleh karena itu penentuan target dalam internal partai harus dilakukaan secara tepat dan benar hal ini agar tidak terjadi kebingungan dalam pelaksanakan kegiatan maupun tugas yang akan dilaksanakan.

Dari penjalasan tentang penentuan target maka, menurut (Pudianto, Doddy dan Sudjijono, 2003) target ialah pemilihan (fokus) kepada suatu segmen tertentu yang ingin dicapai (dianggap secara intensif untuk diarahkan sebagai pendukung utama partai) dalam kaitan lain, targeting adalah keputusan untuk membidik pada suatu kelompok konstituen tertentu yang diperkirakan akan amat mudah untuk diraih.

Pada umumnya target biasanya ditentukan hanya untuk pemilu saja atau pada akan menjelang pemilu, baik itu untuk memperoleh mayoritas kursi DPR, memperoleh mayoritas kursi DPRD, memperoleh suara pada PILKADA, maupun memenangkan pemilihan presiden dan wakil presiden. Hal inilah yang mungkin perlu diperbaiki karena pada umumnya masyarakat tidak hanya dibutuhkan dalam pemilihan tetapi masyarakat diupayakan untuk selalu mendukung segala kegiatan partai sehingga adanya kontrol dari masyarakat untuk melakukan pembenahan disegala bidang.

Dalam proses penentauan target partai politik di Indonesia berupaya melihat hasil suara yang telah dicapai pada pelaksanaan pemilu sebelumnya dengan cara menganalisa kelemahan dan kekuatan yang dimiliki baik itu ditingkatan nasional maupun ditingkatan cabang hingga ranting. Analisa tersebut bertujuan untuk menentukan target yang akan dicapai pada pemilihan umum yang akan dilaksanakan dengan langkah taktis yang dibuat untuk menentukan target yang akan dicapai. Adapun analisis target kalau ditabelkan bisa menjadi seperti gambar dibawah ini:

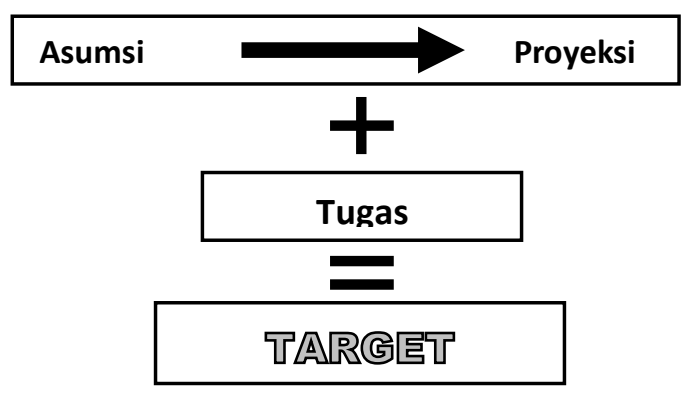

Gambar 2

Analisis Target

Dalam hal ini ada beberapa hal yang harus diperhatikan dalam penentuan target yang Pertama melihat kelebihan dan kelemahan partai, Kedua adalah seberapa jauh perubahan yang dilakukan oleh partai politik dalam sosialisai dan Ketiga, adalah berkaca pada pemilu-pemilu sebelumnya dan letak wilayah daerah pemilihan.

\section{Menumbuhkan Kepercayaan Masyarakat Terhadap Partai (Eksternal) \\ Mengingat pada saat ini masyarakat} kebanyakan tidak lagi percaya dengan partai politik, hal ini disebabkan karena partai politik tidak lagi mengaspirasikan kepentingan masyarakat sehingga Copyright @ 2019, Publik (Jurnal Ilmu Administrasi), ISSN: 2301-573X (Print), ISSN: 2581-2084 (Online) 
masyarakat yang kecewa dengan partai politik mengajukan calon-calonnya tanpa melalui partai politik hal ini terbukti dengan adanya calon independen dalam PILKADA yang undang-undang tentang calon independen masih dalam tahap pembahasan.

Dari berbagai asumsi tersebut, strategi partai politik secara eksternal yaitu menumbuhkan kepercayaan masyarakat terhadap partai, dapat memberikan pemahaman terhadap masyarakat mengenai kondisi lapangan, data dan fakta yang berharga bagi penerapan sebuah strategi pada suatu daerah untuk memperoleh kepercayaan dan dukungan dari masyarakat. Dalam menumbuhkan kepercayaan masyarakat terhadap partai politik strategi yang biasanya dipakai untuk menarik simpati masyarakat adalah:

\section{E. Mendekatkan partai pada kyai dan organisasi-organisasi yang ada di masyarakat.}

Sebagai negara kesatuan yang berasas kekeluargaan, kehendak rakyat yang sangat majemuk dan butuh suasana baru diaspirasikan oleh partai politik baik guna meraih simpati massa. Terkait dengan meraih simapati massa kebanyakan partai yang ada di Indonesia selalu mendekatkan pada kyai atau ulama dan organisasiorganisasi kemasyarakatan. Dalam kaitan ini ulama atau kyai menjadi penting bagi kebanyakan partai karena bisa memobilisasi massa yang diinginkan dan juga menjadi pengontrol kebijakan partai.

Dengan demikian kaitan dengan politik, knowledge yang dimiliki ulama atau kiay merupakan power yang secara potensial dapat digunakan tidak hanya untuk menggalang dukungan massa guna mewujudkan suatu tindakan atau proses politik tertentu, tetapi bahkan untuk mendukung suatu sistem politik atau kekuasaan politik tertentu secara keseluruhan, dan tidak jarang bahkan tanpa reserve (Azra, 2002). Berkat aura sakral yang dimilikinya, kehadiran ulama dalam suatu pertemuan politik semacam kampanye pemilu, dan apalagi jika disertai imbauan ulama untuk mendukung partai atau kekuasaan politik tertentu, bagi massa awam -apalagi yang "mengambang" (floating mass) -bukan sekedar keputusan politik, tetapi sekaligus merupakan fatwa kaagamaan.

Tidak dapat disangkal kekuatan karismatik yang dimiliki ulama atau kyai dapat membawa massa yang banyak hal ini terbukti di pemilu-pemilu sebelumnya. Sadar atau tidak sadar ulama atau kyai bergerak dibidang keagamaan dalam masyarakat yang kemudian dalam proses politik ulama dijadikan figur untuk menarik massa. Apalagi ulama atau kyai diperkuat dengan pemberian status penerus para nabi (waratsa al-anbiya) yang kemudian terjawantahkan dalam karismanya, maka lengkaplah aura yang dimilikinya. Oleh sebab itu masyarakat sering mengikuti perkataan ulama sehingga perlu kiranya bagi partai politik mendekatkan partai pada kyai hal ini tidak terlepas dari strategi partai untuk meraih simpati massa mengingat masyarakat di Indonesia mayoritas beragamakan Islam.

Beberapa partai yang ada tidak hanya cukup mendekatkan diri kepada kyai atau ulama, tetapi juga melibatkannya secara langsung kedalam partai hal ini bisa kita lihat dengan banyaknya kyai atau ulama yang masuk kedalam struktur kepengurusan partai. Perjuangan partai untuk meraih dukungan massa tidak berhenti pada pendekatan paratai pada ulama, tetapi partai politik juga mendekatkan kepada organisasi-organisasi yang ada dimasyarakat baik itu organisasioraganisai kecil maupun organisasi besar, tidak terlepas dari itu NU dan 
Muhammadiyah yang merupakan organisasi Islam yang besar juga menjadi mesin penggerak partai-partai yang ada.

\section{F. Sosialisasi program jangka pendek dan jangka panjang berdasarkan visi dan misi.}

Sosialisasi program merupakan kegiatan atau usaha yang dilakukan oleh partai politik di bidang informasi, himbauan atau bujukan, dan komunikasi serta aktifitas yang bertujuan mendekatkan jarak antara partai politik dan masyarakat pemilih dengan berbentuk program yang telah dirancang baik itu program jangka pendek maupun jangka panjang yang dilakukan atau dijalankan kepada masyarakat maupun dalam internal partai itu sendiri.

Organisasi butuh penampakan atau yang disebut nampak baik organisasi itu sendiri maupun programnya seperti yang dikatakan (Aziz, 2006) sebagai suatu organisasi, eksistensi partai secara mendasar direfleksikan oleh programprogram yang disusun dan dilaksanakannya. Program-program yang disusun pun sungguhnya mempresentasikan cara pandang atau penafsiran partai terhadap realitas historis.

Program merupakan tugas pokok dan fungsi partai politik. Untuk itu, mengukur sebuah keberadaan organisasi partai politik bisa dilihat dari program kerja dan kemanfaatan partai politik bagi masyarakat. Tetapi program partai politik harus terus diawasi dan dikawal oleh masyarakat untuk menunjukkan eksistensinya, seperti yang dikatakan (Ibad, 2018) untuk mendorong partisipasi masyarkat perlu adanya wadah keluhan masyarakat terhadap apa yang dirasa kurang dan dikeluhkan oleh masyarakat sehingga masyakat merasa bertanggung jawab dan merasa memiliki organisasi atau instansi yang ada.
Setiap organisasi memiliki program dan tujuan yang jelas berdasarkan visi dan misi partai itu sendiri, tetapai dalam hal ini program tidak akan dikenal oleh masyarakat tanpa adanya sosialisasi. Mengingat partai politik merupakan penyalur aspirasi masyarakat dan merupakan alat pencapaian kekuasaan, sosialisasi penting dilakukan kepada publik untuk memberikan pemahaman tentang apa yang akan dilakukan dan untuk menarik dukungan terhadap apa yang akan dilakukan oraganisasi.

Sosialisasi program biasanya dilakukan dalam dua jenjang yaitu ada sosialisasi program jangka pendek dan jangka panjang. Biasanya sosialisasi jangka pendek adalah perebutan kekuasaan atau yang disebut pemenangan pemilu baik itu pemilihan presiden, PILGUB, maupun PILKADA, tidak hanya itu program jangka pendek dilakukan dan disesuaikan dengan kebutuhan partai dan masyarakat. Akan tetapi program jangka panjang dilakukan dalam satu kepengurusan yang biasanya dalam satu kepengurusan yaitu lima tahun.

G. Kampanye dengan bentuk pemasangan atribut partai (spanduk, stiker, dll), pemamfaatan media elektronik, pemamfaatan media massa, dan melalui bakti sosial.

Kampanye merupakn sebuah proses pengumpulan massa pendukung dan kampanye juga bisa dikatakan promosi kepada pemilihnya yang merupakan tahapan penting, karena dalam kampanye merupakan sarana bagi setiap partai politik untuk menyampaikan visi, misi dan programnya sebagai proses menarik simpatik massa.

Kegiatan kampanye pemilu adalah proses mempersuasi khalayak untuk bersedia menerima, mendukung, dan akumulasinya adalah memilih partai atau kandidat yang dikampanyekan (Anwar, M. Khoirul dan Salvina, 2006). Sebenarya Copyright @ 2019, Publik (Jurnal Ilmu Administrasi), ISSN: 2301-573X (Print), ISSN: 2581-2084 (Online) 
dalam kampanye ini sungguh banyak yang dilakukan oleh partai politik untuk meraih dukungan massa, dari itu kampanye merupakan bentuk dari komunikasi yang dilakukan oleh partai politik.

Sedangkan Paisley mengatakan bahwa kampanye merupakan bentuk komunikasi kepada publik secara lebih terkontrol baik isi pesan maupun bentuk kegiatannya. Dia memberikan definisi kampanye komunikasi publik sebagai "someone's to influence someone else's belifes or behavior, using communicated appeals". Kampanye juga merupakan strategi kontrol sosial dalam rangka mengarahkan psikologi dan perilaku pemilih untuk menyesuaikan dan pada saatnya menuruti apa yang diprogramkan oleh partai politik. Ujud yang paling nyata kegiatan kampanye politik sebagai strategi kontrol sosial adalah provokasi (Anwar, M. Khoirul dan Salvina, 2006).

Dalam kegiatan kampanye strategi maupun pola kampanye sangat bermacammacam, dapat kita lihat partai-partai yang ada di Indonesia pada saat ini. Cara kampanye partai politik ini biasanya dilakukan dengan cara pemasangan atribut partai (baik itu spanduk, stiker, maupun kaos-kaos yang dibagikan kepada masyarakat), pemamfaatan media elektronik, pemamfaatan media massa, dan melalui bakti sosial dengan melibatkan tokoh masyarakat maupun orang yang berpengaruh di daerahnya. Hal ini semua dilakukan untuk memperoleh simpati masyarakat untuk ikut serta dalam proses yang dilakukan partai tertentu baik itu program maupun untuk menjadi simpatisan partai.

Dalam penelitian-penelitian yang dilakukan sebelumnya (Lindawati, 2014) (Ibad, 2008) dan (Sugiarto, Pratiwi, Akbar, Politik, \& Soedirman, 2014) dijelaskan bahwa kampaye yang dilakukan semuanya hampir sama dan bisa dikatakan sama, sehingga masyarakat menganggap bahwa kampaye yang dilakukan partai politik secara umum hanya untuk menarik dukungannya saja dan sedikit berdampak bagi kesejahteraan masyarakat. Artinya program kampaye hanyalah program yang bermasa dan waktu sehingga tidak berdampak secara kontinu kepada masyarakat.

\section{PENUTUP}

\section{Kesimpulan}

Strategi partai politik merupakan cara, trik, taktik maupun usaha (dalam hal itu ada sebuah pilihan yang harus dipilih) berdasar kemampuan yang dimiliki untuk mencapai tujuan yang telah disusun secara rapi. Akan tetapi secara umum dalam organisasi strategi partai politik dikelompokkan dalam lima hal, yaitu: Pertama, membangun dan memantapkan komunitas partai ditingkatan grass root, karena partai tidak dapat menafikan dukungan yang besar berasal dari masyarakat kecil. Kedua, konsolidasi dengan memperkuat struktural organisasi dan kader partai mulai tingkatan struktur terbawah. Ketiga, mengaplikasikan program yang menyentuh masyarakat secara langsung sehingga masyarakat tidak lagi merasa dibohongi dengan adanya janji-janji yang biasanya dilakukan pada kampanye-kampanye, masyarakat pada saat ini tidak butuh janji semata tetapi realisasi. Keempat, memperluas basis dukungan dengan merekrut semua komponen masyarakat yang berasal dari dunia pendidikan, pengusaha, birokrat, ulama, maupun masyarakat biasa. Yang terakhir atau yang Kelima, merubah kinerja pengurusan yang formal normatif menjadi aplikatif sehingga selalu mengedepankan 
tindakan dan gerakan dari pada sekedar teori.

\section{Saran}

Dalam penelitian ini perlu dipikirkan bersama dari kelima garis besar strategi yang dilakukan yang dilakukan partai adalah sebuah proses atau rentetan dari perjuangan partai politik untuk mencapai tujuan sesuai dengan visi dan misi partai politik. Dalam hal itu, partai politik harus bisa menjawab kebutuhan-kebutuhan masyarakat ditengah masyarakat yang krisis akan kepercayaan kepada partai politik.

Dalam hal strategi partai politik perlu juga diperhatikan: pertama, perlu peningkatan dan kualitas strategi itu sendiri yang tujuannya tidak sekedar meraih dukungan tetapi lebih dari itu bisa membatu tercapainya visi misi partai. kedua, konsolidasi dengan memperkuat struktural tidak hanya dilakukan disaat-saat akan menjelang pesta demokrasi/ pemilu tetapi perlu waktu yang lama dan kossisten karena partai merupakan organisasi yang terus akan berkembang. ketiga, programprogram kerja partai politik harus tetap berjalan dan dilaksanakan karena tujuan partai politik bukan hanya merebut kekuasan dan membagi-baginya tetapi perlu dipikirkan kesejahteraan masyarakar dari bidang sosial, politik, dan budaya. keempat, perekrutan dan pengkaderan harus ada mekanisme yang jelas dan berjenjang sehingga partai politik memiliki kader yang benar-benar militan, berintegritas, tidak instan, tidak merasa berkuasa dalam partai, dan tidak siapa dekat dia jadi kader. kelima, strategi butuh aplikatif bukan hanya teori.

\section{DAFTAR PUSTAKA}

Anwar, M. Khoirul dan Salvina, V. (2006). Prilaku Partai Politik; Studi Prilaku
Partai Politik Dalam Kampaye Dan Kecendrungan Pemilih Pada Pemilu 2004. Malang: UMM Press.

Aziz, A. (2006). Politik Islam Politik:

Pergulatan Ideologis PPP Menjadi

Partai Islam. Yogyakarta: Tiara

Wacana.

Azra, A. (2002). Reposisi Hubungan

Agama Dan Negara; Merajut

Kerukunan Antarumat. Jakarta: PT

Kompas.

Dhakidea, D. (2004). Partai-Partai Politik

Indonesia Ideologi Dan Program

2004-2009. Jakarta: PT Kompas

Media Nusantara.

Hidayat, Komaruddin dan Haryono, M. Y. (2004). Manuver Politik Ulama;

Tafsir Kepemimpinan Era Reformasi

Dan Dialektika Ulama-Negara.

Yogyakarta: Jalasutra.

Hidayat, I. (2002). Teori-Teori Politik.

Malang: Panti Asuhan Nurul Abyadh.

Ibad, S. (2008). Strategi Partai Politik

Dalam Meraih Dukungan Massa (

Studi Studi Pada Partai Persatuan

Pembangunan Kota Malang 2007.

2008) (universitas muhammadiyah malang). Retrieved from http://eprints.umm.ac.id/id/eprint/466 4

Ibad, S. (2018). Kewenangan Badan

Perencanaan Pembangunan Kota (Bappeko) Malang Dalam

Perencanaan, Kordinasi, Dan

Pengendalian Tata Ruang Kota.

DIALEKTIKA : Jurnal Ekonomi Dan

Ilmu Sosial, 1(2), 23-48.

https://doi.org/10.36636/dialektika.v1i 2.68

Lindawati, D. S. (2014). Strategi Partai Politik dalam Menghadapi Pemilu 2014. Politica, 4(2), 287-312.

Nursal, A. (2004). Political Marketing:

Strategi Memenangkan Pemilu.

Jakarta: PT Gramedia Pustaka Utama. Pudianto, Doddy dan Sudjijono, B. (2003). Copyright @ 2019, Publik (Jurnal Ilmu Administrasi), ISSN: 2301-573X (Print), ISSN: 2581-2084 (Online) 
Menejemen Pemasaran Partai Politik.

Jakarta: Citra Mandala Pratama.

Soebekti, E. Achmad, dan N. (2002). Di

Saat Ekonomi Terpuruk Partai Politik

Rame-Rame Pecah Kongsi. Jakarta:

PT Gria Media Prima.

Sugiarto, B., Pratiwi, O. C., Akbar, A. A.

S., Politik, J. I., \& Soedirman, U. J. (2014). Strategi pemenangan dalam pemilihan kepala daerah (Head of regency election winning strategy). Masyarakat, Kebudayaan Dan Politik, Vol. 27(No. 3), 143-151.

Zed, M. (2003). Metode Penelitian

Kepustakaan. Jakarta: Yayasan Obor Indonesia. 